\title{
Analysis the Relationship between Social Media and Education System in Kurdistan region of Iraq Using Chi-Square Test
}

\author{
Jihan Abdulazeez Ahmed Rassool \\ Computer Science College, University of Duhok, Duhok, Kurdistan Region - Iraq
}

\section{ABSTRACT}

At the beginning of $21^{\text {st }}$ century, the world has faced many challenges and rapid change in the educational environments. The globalization and the birth of internet lead the appearance of social media. The new education system has to cope with the above developments and to realize the demand of the new technologies and their effect on the students learning life. To analysis the effect of social network on education, the Chi-Square test was used to indicate the association relation between the Social Media tools and education. I have used real data of students from two University the first is Government (University Of Duhok) and the other is private-University (Nawroz University) at Duhok-Kurdistan region of Iraq. This paper indicates the association and correlation between the education and the Social Media, and conclude that the more than 85\% of students used Social Media for communication and only approximate $45 \%$ used it for learning and teaching, also this paper indicates a need to orientate and guidance the education system in Kurdistan towered of using the social media in education for elevation of education quality and enhancing their learning because social media facilitate the learning system by participating the educations knowledge in different places of world.

KEYWORDS : Social Media, Chi-Square test, Students Database.

\section{INTRODUCTION}

At the beginning of 21st century the world has faced many challenges such as the globalization and the birth of internet; all these lead the appearance of social media. The new education system has to cope with the above developments and to realize the demand of the technologies and their effect on the students learning life. The social media is a social interaction among people in which they create, share or exchange information and ideas in virtual communities and networks. Social media is defined by Andreas Kaplan and Michael Haenlein as "a group of Internet-based applications that build on the ideological and technological foundations of Web 2.0 and that allow the creation and exchange of user-generated content."[1] While Gitanjali Kalia defines Social Media in a simple

Academic Journal of Nawroz University

(AJNU) Volume 7, No 4 (2018).

Regular research paper : Published 21 December 2018

Corresponding author's e-mail : drjihanrasool@gmail.com

Copyright (02017 Jihan Abdulazeez Ahmed Rassool.

This is an open access article distributed under the Creative Commons Attribution License. way as a "a tool that lets students, parents, and educators collaborate online" [2]. Social media network works in virtual environment as tools for the communication, interaction, creation, sharing and exchanging information and ideas among people. Social media invents a new way for communication between people, courtiers, companies, and organization; it let them share their ideas, and gathering information. The phrase "social networking" can carry some negative references for educators, that is why the SM for education is called as "educational networking" and this may be a valuable tools of more objectively in education [5][6][7]. The SM can also help the students in finding a college as IvyWise sayed "social media outlets are effective supplemental research tools, it equipment yourself with all the information possible will help you develop a college list that meets all of your interests and needs" [9]. Students can use SM effectively in their study and can get as much as possible of information they need by using blogging services, and group services [8]. Social media have many advantages for helping the students in their education such as [5][8]:

1. The social media increased the Collaboration between students and help students to work in group by increasing the rate and quality of collaboration for 
student, which helps then to share information and increase the productivity.

2. The social media increase the creativity: the users can upload and share pictures and videos very quickly and easily which help students to increase their career.

3. Social media help students to find professional and good people which are great resources

4 . The social media is a best and easy way of communication.

The Twitter and blogs are two examples tools of SM and they are applied in the Department of Library and Information Science at Mzuzu University which is a public university in Malawi. The results indicated that Twitter and blogs are brave for the much approach to teaching, these two tools encourage the students in their learning. [3] In America most SM tools that are used by the young adults' people are Snapchat and Instagram while the majority of Americans people use YouTube and Facebook. [4]. Chi squared model is a statistical analysis which is useful in determining the significant analysis of association rules [11,12]. The Chi Square test is wieldy used in mining algorithms because it is easy, useful and quickly determined. If the requirements is data categories the Chi Square test provide a greatly improvement in analyzing the association and correlation between independent data categories [13]. The rest of the paper is organized as follows: Section 2 presents a brief description of Chi-Square test. A numerical result and experiment is discussed in section 3. Finally, conclusion is given in Section 4 .

\section{Chi-Square Test}

Chi Square is a statistical theory that can be used to discover the correlation relation between two attributes, it helps in identifying if two variables are related to each other. The term 'chi square' (pronounced with a hard 'ch'): is come from the Greek letter $\square$ which is used to define the distribution of the variables, (also known as the Pearson $\square 2$ statistic) [12] [14]. It will be seen that the elements on which this distribution is based are squared, so that the symbol $\square 2$ is used to denote the distribution. [15]

The steps of Chi Square Test are as Follow [14]:

1.Summarize data and make a hypothesis based on related questions.

2. Determine the Observed values.

3. Compute the expected frequencies :

$$
\text { Expected }=\frac{\text { (total of rows } * \text { total of columns) }}{\text { sample size }}
$$

4. Compute Chi Square:

$$
\chi^{2}=\sum \frac{(\text { observed-expected })^{2}}{\text { expected }}
$$

5. Compute the degrees of freedom:

$\mathrm{df}=($ no. of rows -1$)($ no. of columns -1$)$

6.Search in the Chi-Square Distribution Table for the chi-square statistic [16].

7.If chi-square statistic in table $>$ calculated chi-square value, reject not null hypothesis and vice versa.

\section{Experiments and Results}

In this study, the data gathered from the students of the two universities the first is Government which is University Of Duhok UOD and the other is private, Nawroz University NU, at Duhok-Kurdistan region of Iraq. The data was gathered during 2017-2018, and included records of 115 students from the NU, and 90 students from the UOD. A survey analysis with the representative of students had been conducted to address the foundation status and the different readiness parameters in implementing a social media tools in education environment. On the content of survey being made and the efforts being directed according to the Student prospective, the data collected is depending on many questions and the survey has been analyzed. The students answer many questions relating to the SM such as:

A. Are students (you) familiar with the application of social media (hold at least one social media account; Instagram, Snapchat, Twitter and Facebook.)?

B. Are Social Media tools simple or complex?

C. Do you (students) used Social Media tools in your education?

D. How many hours a day do you check your social media site while you doing your homework?" $(<=>$ than 5).

E. Do you use Social Media for communication with your friends?

We denote these questions as $\mathrm{A}, \mathrm{B}, \mathrm{C}, \mathrm{D}, \mathrm{E}$ respectively, the answer to these question consist of three state: YES, $\mathrm{NO}$, and Unknown, the Unknown answers contain the answers of (unknown or no comment) or in some cases the students didn't answer because they were absent at their class. The unknown answer was rejected because it doesn't lead to any results. The output of our survey will give as the numbers of acceptance and the number of not-acceptance of these queries; the row percentages indicate the percentage association between the education and the $\mathrm{SM}$, according to the number of answering Yes/No, as seen in Table 1, and Table 2 for both of NU and UOD, respectively. Fig. 1, and Fig 2, shows the yes/no percentage corresponding to each questions relating to NU and UOD respectively.

Table (1) : Data from University of Nawroz NU, and the corresponding percentages 


\begin{tabular}{|c|c|c|c|}
\hline Questions & No. of YES & No. of NO & Total \\
\hline $\begin{array}{c}\mathrm{A} \\
\text { percentage } \% \text { of Education association within SM }\end{array}$ & $\begin{array}{c}82 \\
(71 \%)\end{array}$ & $\begin{array}{c}29 \\
(25 \%)\end{array}$ & 111 \\
\hline $\begin{array}{c}\mathrm{B} \\
\text { percentage } \% \text { of Education association within SM }\end{array}$ & $\begin{array}{c}80 \\
(70 \%)\end{array}$ & $\begin{array}{c}30 \\
(26 \%)\end{array}$ & 110 \\
\hline $\begin{array}{c}\mathrm{C} \\
\text { percentage } \% \text { of Education association within SM }\end{array}$ & $\begin{array}{c}44 \\
(38 \%)\end{array}$ & $\begin{array}{c}68 \\
(59 \%)\end{array}$ & 112 \\
\hline $\begin{array}{c}\mathrm{D} \\
\text { percentage } \% \text { of Education association within SM }\end{array}$ & $\begin{array}{c}49 \\
(43 \%)\end{array}$ & $\begin{array}{c}64 \\
(56 \%)\end{array}$ & 113 \\
\hline $\begin{array}{cc} & E \\
\text { percentage } \% \text { of } & \text { Education association within SM }\end{array}$ & $\begin{array}{c}97 \\
(84 \%)\end{array}$ & $\begin{array}{c}16 \\
(14 \%)\end{array}$ & 113 \\
\hline Total & 352 & 207 & 559 \\
\hline
\end{tabular}

Table (2) : Data from University of Duhok UOD

\begin{tabular}{|c|c|c|c|}
\hline Questions & No. of YES & No. of NO & Total \\
\hline $\begin{array}{c}\text { A } \\
\text { percentage } \% \text { of Education association within SM }\end{array}$ & $\begin{array}{c}79 \\
88 \%\end{array}$ & $\begin{array}{c}9 \\
10 \%\end{array}$ & 88 \\
\hline $\begin{array}{c}\text { B } \\
\text { percentage } \% \text { of Education association within SM }\end{array}$ & $\begin{array}{c}57 \\
63 \%\end{array}$ & $\begin{array}{c}30 \\
33 \%\end{array}$ & 87 \\
\hline $\begin{array}{c}\mathrm{C} \\
\text { percentage } \% \text { of Education association within SM }\end{array}$ & $\begin{array}{c}33 \\
36 \% \\
\end{array}$ & $\begin{array}{c}56 \\
62 \% \\
\end{array}$ & 89 \\
\hline $\begin{array}{c}\mathrm{D} \\
\text { percentage } \% \text { of Education association within SM }\end{array}$ & $\begin{array}{c}24 \\
27 \%\end{array}$ & $\begin{array}{c}60 \\
67 \% \\
\end{array}$ & 84 \\
\hline $\begin{array}{cc}\text { percentage } \% \text { of } & E \text { Education association within SM }\end{array}$ & $\begin{array}{c}82 \\
91 \%\end{array}$ & $\begin{array}{c}7 \\
8 \%\end{array}$ & 89 \\
\hline Total & 275 & 162 & 435 \\
\hline
\end{tabular}

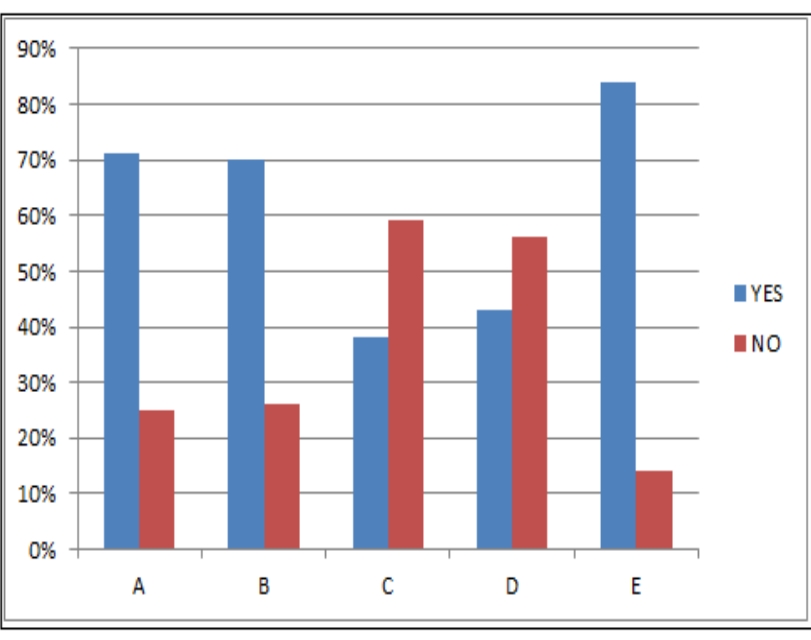

Fig (1) : percentage of answering YES/NO corresponding to each question for NU

The Table 3 and Table 4 show the contingency tables for both Universities, the expected frequency value are computed by using the 1 , and are written between parentheses. The Chi Square is computed by using 2 . For example, consider the instance (YES, Question A) from table 1 of case study of NU, to compute the

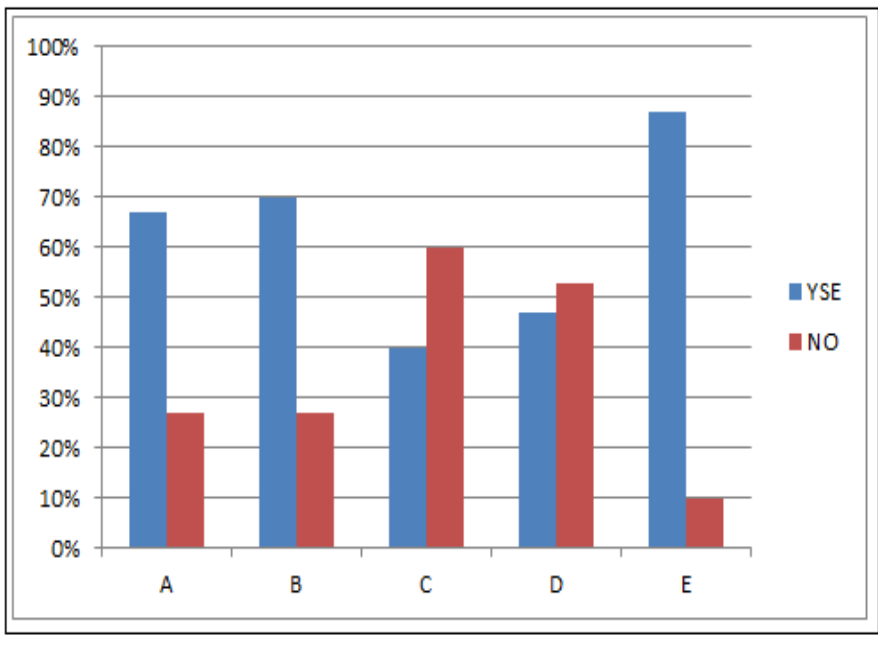

Fig (2) : Percentage of answering YES/NO corresponding to each question for UOD

expected frequencies value we use 1 as showing below:

Expect of instance (YES, Question $\mathrm{A})=$ (count(YES)* count (answer to Question A))

$$
\begin{gathered}
=\frac{\mathbf{N}}{559} \\
=70
\end{gathered}
$$


Table (3) : Calculated of the Expected Value for UN

\begin{tabular}{|c|c|c|c|}
\hline Questions & No. of YES & No. of NO & Total \\
\hline A & $\begin{array}{c}82 \\
(70)\end{array}$ & $\begin{array}{c}29 \\
(41)\end{array}$ & 111 \\
\hline Observed Frequency Expected Frequency & $\begin{array}{c}80 \\
(69)\end{array}$ & $\begin{array}{c}30 \\
(41)\end{array}$ & 110 \\
\hline B & $\begin{array}{c}44 \\
(71)\end{array}$ & $\begin{array}{c}68 \\
(41)\end{array}$ & 112 \\
\hline Observed Frequency Expected Frequency & $\begin{array}{c}49 \\
(71)\end{array}$ & $\begin{array}{c}64 \\
(42)\end{array}$ & 113 \\
\hline Observed Frequency Expected Frequency & 97 & 16 & 113 \\
\hline D & $(71)$ & $(42)$ & \\
\hline Observed Frequency Expected Frequency & 207 & 559 & 352 \\
\hline
\end{tabular}

Table (4) : Calculated of the Expected Value for UOD

\begin{tabular}{|c|c|c|c|}
\hline Questions & $\begin{array}{c}\text { No. of } \\
\text { YE6S }\end{array}$ & No. of NO & Total \\
\hline $\begin{array}{c}\text { A } \\
\text { Observed Frequency Expected Frequency }\end{array}$ & $\begin{array}{c}79 \\
(55)\end{array}$ & $\begin{array}{c}9 \\
(33)\end{array}$ & $\mathbf{8 8}$ \\
\hline B & $\begin{array}{c}57 \\
(55)\end{array}$ & $\begin{array}{c}30 \\
(32)\end{array}$ & $\mathbf{8 7}$ \\
\hline Observed Frequency Expected Frequency & $\begin{array}{c}33 \\
(56)\end{array}$ & $\begin{array}{c}56 \\
(33)\end{array}$ & $\mathbf{8 9}$ \\
\hline $\begin{array}{c}\text { C } \\
\text { Observed Frequency Expected Frequency }\end{array}$ & $\begin{array}{c}24 \\
(53)\end{array}$ & $\begin{array}{c}60 \\
(31)\end{array}$ & $\mathbf{8 4}$ \\
\hline D & $\begin{array}{c}82 \\
(56)\end{array}$ & $\begin{array}{c}7 \\
(33)\end{array}$ & $\mathbf{8 9}$ \\
\hline Observed Frequency Expected Frequency & 275 & 162 & $\mathbf{4 3 7}$ \\
\hline E
\end{tabular}

By applying chi-square test using R language we get the results, as an example Fig 3 shows the Chi square for UoD. 


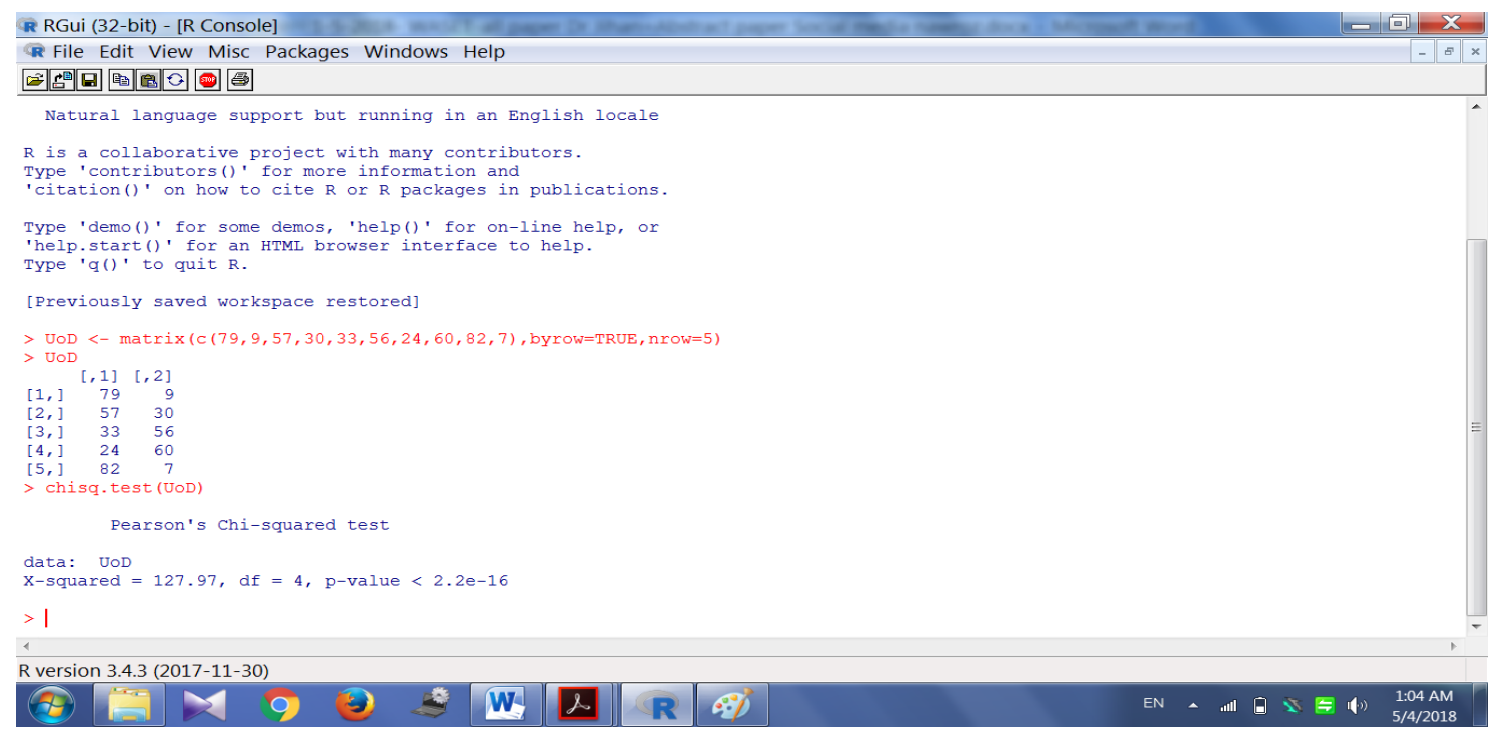

Fig (3) : The Result of Chi-Square Test for UoD Using R language.

By using 3, we calculated the degree of freedom for both universities, were numbers of columns are equal 2, and numbers of rows are equal 5 , as shown below :

Calculate degrees of freedom for: $(r-1)(\epsilon-1)=(5-1)(2-1)$ $=4$

The computed of the Chi-Square test of independences for both case studies are shown below:

$\mathrm{X}$-squared $=81.073, \mathrm{df}=4, \mathrm{p}$-value $<2.2 \mathrm{e}-16$ for $\mathrm{NU}$.

X-squared $=127.97, \mathrm{df}=4, \mathrm{p}$-value $=2.2 \mathrm{e}-16$ for UoD.

The Chi Square Test of Independence was computed using $\mathrm{R}$ statistical programming environment., The Chi-
Square Test for Case study 1, NU is: $\square 2=81.073$ for the freedom $=4$, the $\square 2$ value needed to reject the hypothesis at the 0.05 significance level is 9.49 determined from Chi-square statistic on a Chi-square distribution table, as shown in Fig 4, this table is typically available at any textbook on statistics [13]. Since our computed value is above this, we can reject the hypothesis that the education and Social Media Tools are independent and conclude that the two attributes are (strongly) correlated for the given group of students.

\begin{tabular}{|c|c|c|c|c|c|}
\hline \multirow{2}{*}{ Df } & \multicolumn{5}{|c|}{ Level of significance } \\
\hline & .10 & .05 & .02 & .01 & .001 \\
\hline 1 & 2.71 & 3.84 & 5.41 & 6.64 & 10.83 \\
\hline 2 & 4.60 & 5.99 & 7.82 & 9.21 & 13.82 \\
\hline 3 & 6.25 & 702 & 9.84 & 11.34 & 16.27 \\
\hline 4 & 78 & 9.49 & 11.67 & 13.28 & 18.46 \\
\hline 5 & 9.24 & & 13.39 & 15.09 & 20.52 \\
\hline 6 & 10.64 & 12.59 & 15.03 & 16.81 & 22.46 \\
\hline 7 & 12.02 & 14.07 & 16.62 & 18.48 & 24.32 \\
\hline 8 & 13.36 & 15.51 & 18.17 & 20.09 & 26.12 \\
\hline 9 & 14.68 & 16.92 & 19.68 & 21.67 & 27.88 \\
\hline 10 & 15.99 & 18.31 & 21.16 & 23.21 & 29.59 \\
\hline 11 & 17.28 & 19.68 & 22.62 & 24.72 & 31.26 \\
\hline 12 & 18.55 & 21.03 & 24.05 & 26.22 & 32.91 \\
\hline 13 & 19.81 & 22.36 & 25.47 & 27.69 & 34.53 \\
\hline 14 & 21.06 & 23.68 & 26.87 & 29.14 & 36.12 \\
\hline 15 & 22.31 & 25.00 & 28.26 & 30.58 & 37.70 \\
\hline 16 & 23.54 & 26.30 & 29.63 & 32.00 & 39.25 \\
\hline 17 & 24.77 & 27.59 & 31.00 & 33.41 & 40.79 \\
\hline 18 & 25.99 & 28.87 & 32.35 & 34.80 & 42.31 \\
\hline 19 & 27.20 & I 0.14 & 33.69 & 36.19 & 43.82 \\
\hline
\end{tabular}

Fig (4) : a screenshot of a Chi-Square Distribution Table

The Chi-Square Test for Case study 2 UoD is: $\square 2=$ 127.97 , for the freedom $=4$, the $\square 2$ value needed to reject the hypothesis at the 0.05 significance level is 9.49 . Since our computed value is above this $(127.97>9.49)$, we can reject the hypothesis that the education and Social Media Tools are independent and conclude that the two attributes are (strongly) correlated for the given group of students. The results of both case studies indicate that there are an association and relation between the Social Media Tools and the Education System in Universities, and that the students need these tools for elevation of education quality and enhancing their learning. As seen in Table 1 and Table 2 that the percentage of answering Yes for Question E (Using SM 
for Communication) is $84 \%$ and $91 \%$ for NU and UOD respectively, the percentage indicates that the most usage of student of SM tool is for Communication, that they used it for communicate among themselves to distribute the lecture and time table of study, while the percentage of answering Yes for Question C and D (Using SM for helping them in their education) is $44 \%$ and $49 \%$ for NU and $36 \%$ and $27 \%$ for UOD respectively, which is very low and that lead to the negative response. That is why the Education System in Duhok/ Kurdistan Region of Iraq needs guidance towered of using the social media tools in education to cooperate with technology and also to raise the education quality and enhancing.

\section{Conclusion}

In this Study the meaning of social media were carried out and explained and the utilization of Social Media tools in the field of education was point out. We have investigated the association relation between SM tools and education, by using Chi Square Test. The case studies were two Universities, Government and private (University Of Duhok and Nawroz University) at Duhok-Kurdistan region of Iraq. The results indicate that there are a correlation relation between SM tools and Education system. The use of the social media technique in education may provide us with more varied and significant findings, and may lead to the increase in the quality of education. The qualitative information which depends on the observation and documentary analysis shows that the majority of students believe that SM is the most useable and simplest tools for communication which is about approximately $86 \%$ and $36 \%$ for both NU and UoD respectively, while there is a lack of student's ability to responds to advantages of these tools in education which is about approximately $46 \%$ and $27 \%$ for both $\mathrm{NU}$ and UoD respectively which is very low value, that is why the education in Kurdistan need innovate system to deal with the new technologies and using SM tools in education systems. The combination of Chi Square Test with other techniques is an open issue.

\section{References}

1.Kaplan Andreas M. Haenlein Michael, (2010), "Users of the world, unite! The challenges and opportunities of social media". Business Horizons 53 (1). p. 61.

2.Gitanjali Kalia, (2013), A Research Paper on Social media: An Innovative Educational Tool, Chitkara University, Punjab, Issues and Ideas in Education, Vol. 1, March pp. 43-50.

3.Winner Dominic Chawinga, (2017), “Taking social media to a university classroom: teaching and learning using Twitter and blogs", Chawinga International Journal of Educational Technology in Higher Education (2017) 14:3, DOI 10.1186/s41239-017-0041-6, Springer.
4. Aaron Smith and Monica Anderson, (2018), "Social Media Use In 2018", (c) Pew Research Center 2018 at www.pewressearch.org.

5.Srivastava, Preeti, (2012), "Social Networking \& Its Impact on Education-System in Contemporary Era" International Journal of Information Technology Infrastructure, Volume 1, No.2, November - December, ISSN 23202629

6.Srivastava, Preeti, (2011), "Professional Development of Teacher Educator Integrating through ICT", Paper presented at the National Seminar,"' Current Issues in Teacher Education." [UGC-SAP], CASE, Faculty of Education and Psychology, the M.S. University. Of Baroda, Vadodara, March 14-15.

7.Educational Networking, , (2012), Educational

Networking. [Online], Available:

http://www.educationalnetworking.com.

8.Sreeja Rajesh, Jithin Michael, (2015), "Effectiveness of Social Media in Education", International Journal of Innovative Research in Advanced Engineering (IJIRAE) ISSN: 2349-2163, Issue 10, Volume 2.

9. How to Use Social Media in Your College Search. IvyWise Volume 9 Issue 3.

10. Toni Ahlqvist, Asta Bäck, Minna Halonen, Sirkka Heinonen, (2008), "Social Media Roadmaps Exploring the futures triggered by social media" , ISBN 978-95138-7246-5 (soft back ed.), Copyright @ VTT.

11. Rocco J. Perla and 2James Carifio, (2006), “Use of the Chi-square Test to Determine Significance of Cumulative Antibiogram Data", American Journal of Infectious Diseases 1 (4): 162-167, 2005, ISSN 1553-6203, (C) Science Publications.

12. J. Magidson, (1994), The CHAID approach to segmentation modeling: CHI-squared automatic interaction detection". In R. P. Bagozzi, editor, Advanced Methods of Marketing Research, pages 118159. Blackwell Business.

P. Meesad, P. Boonrawd and V. Nuipian, (2011), “A Chi-Square-Test for Word Importance Differentiation in Text Classification", International Conference on Information and Electronics Engineering, IPCSIT vol.6, IACSIT Press, Singapore.

13. Jiawei Han and Micheline Kamber, (2006), "Data Mining: Concepts and Techniques, Second Edition", Elsevier.

14. P. Saengsiri, P. Meesad, S. Na Wichian and U. Herwig, (2010), "Comparison of Hybrid Feature Selection Models on Gene Expression Data," IEEE International Conference on ICT and Knowledge Engineering, pp.13 -18.

15. Fisher RA, Yates F, (1974), "Statistical tables for biological, agricultural and medical research, Sixth edition", Addison Wesley Longman Ltd. 